\title{
r r r
}

تأثير استخدام بعض أساليب التسهيلات العصبية العضلية على تحسين مستوى الأداء لناشئي الكار اتيه

\section{د/مهنز أحمد علي فر غلي}

المقدمة ومشكلة البحث :

أصبح التدريب الرياضي بصوره المتعددة عملية لها دورها المهم في المجتمعات المعاصرة فقد صار مجالا للتنافس بين كافة قطاعات المجتمع ويُعد التدريب الرياضي الوسيلة الأساسية التي تعمل علي تلبية متطلبات النشاط الرياضي وتطويره بما بتتاسب مع الهدف المنشود وكلما تقدم مستوي التتافس بين الأفراد زادت الحاجة إلي اتباع أساليب حديثة في التــدريب للارثقاء بهذه المستويات.

ويذكر "أحمد محمود" (1991م) أن رياضة الكاراتية مثلها مثل أي رياضة لها مسابقات متعددة ولكل مسابقة خصائصها فهناك مسابقات القتال الفعلي الكوميتية (kumite) ومسابقات القتال الوهي الجملة الحركية (kata) بالإضافة إلى وجود بطو لات داخل المسابقة

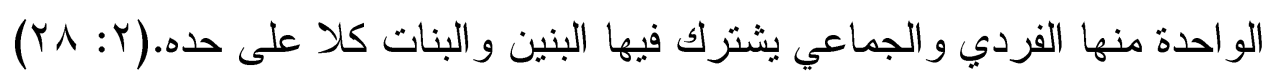
وفى هذا الصدد يشير "محمد علاوى" (Y99 (1) أن الفرد الرياضي لن يستطيع إتقان المهارات الحركية الأساسية لنوع النشاط الرياضي الذي يتخصص فيه في حالة افتقاره للقدرات البدنية الضرورية لهذا النوع من النشاط الرياضي وان تطوير مستوى القدرات الحركية لا يتم بصورة مجردة بل ويتم من خلال الخصائص المميزة لنوع النشاط الرياضي

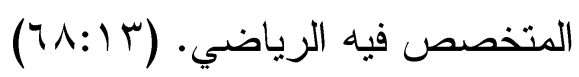

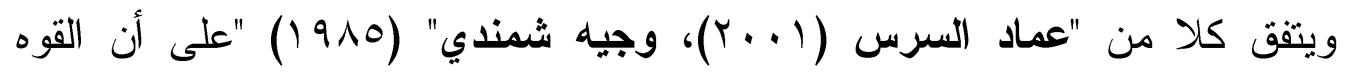
المميزة بالسرعة و المرونة والرشاقة وسرعة رد الفعل هم أهم القدرات البدنية التي يجب أن يمتلكها لاعب الكار اتية بنسبة عالية شرط أساسي للوصول للمستويات الرياضية العالية $(1 \wedge: 1 \vee) \cdot(r \div: 11)$

ويرى "وجيه شمندى" (ب99 (أن المرونة من العو امل البدنية الأساسية الضرورية في رياضة الكار اتية خاصة عند تنفيذ الأداء المهارى والخططي حيث يتطلب من اللاعب أداء

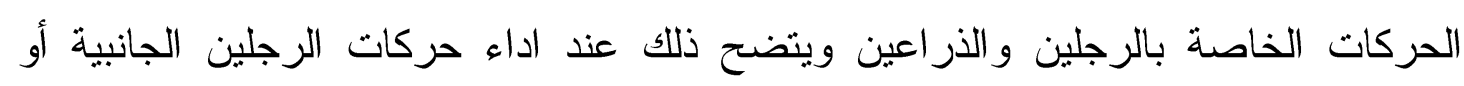
الدائرية أو حركات لف الجذع لتنفيذ أداء لكمات قوية وسريعة هذا يتم سواء في تتفيذ حركات الكاتا او الكوميتية حيث أن المدي المثالي للحركة له أهميته البيولوجية والميكانيكية عند الأداء. 


\section{rY}

ويري "عمرو حلاويش" (r . +rم) أن الركلة الدائرية من أهم الركلات في رياضة الكار اتئة بشكل عام وتخصص الكوميتية بشكل خاص ويرجع ذلك إلى العديد من الميزات التي تتميز بها هذه التها

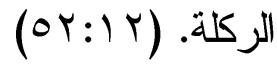

كما يذكر "ميشيل اتير Michael Atter " (990) (1900) أن طريقة استخدام التسهيلات العصبية تطورت في أواخر الأربعينات وبداية الخمسينات وذلك بالتأكيد على ضرورة التربل التخدام المقاومات القصوى من بداية الددى الحركي وحتى نهايته، وذللك باستخدام مزيج من الحركات

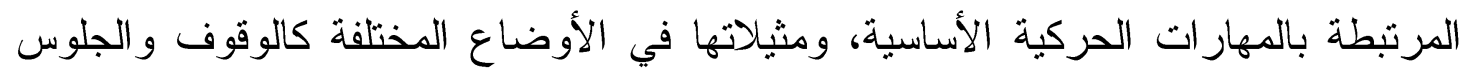
والرقود، وتتضمن هذه الطريقة الانقباضات الأيزو مترية وكذلك الانقباضات المتحركة سواء الأوضاء كانت بالتطويل أو بالتقصير إلى جانب الحركات السلبية، هذا ويمكن تطبيق التدريبات

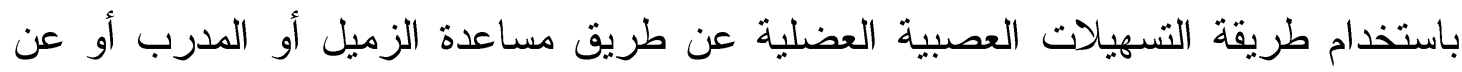

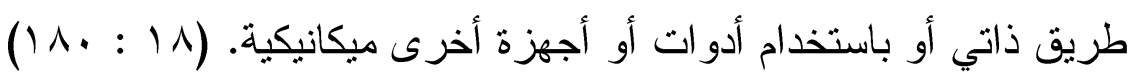

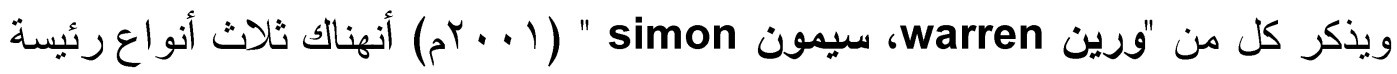

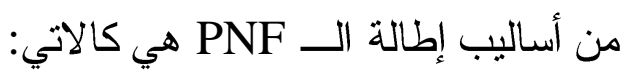
Hold -Relax التيثيث - الاسترخاء Hold-Relax - With Agonist التبثيت - الاسترخاء مع انقباض العضلات المحركة

Contraction

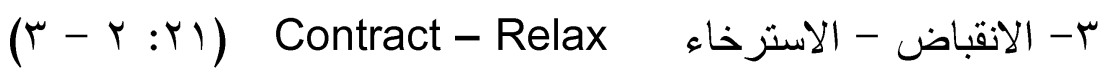
ومن خلال العرض السابق استدعت الحاجة إلى التعرف علي توظيف طرق التسهيل العصبي العضلي للمستقبلات الحسية (PNF) في رفع كفاءة الانقباض العضلي بإيقاعات

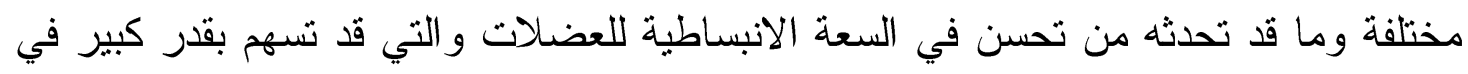

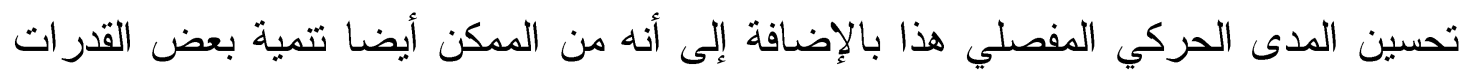

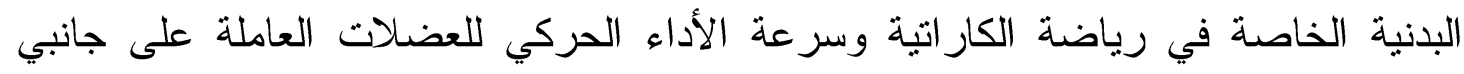

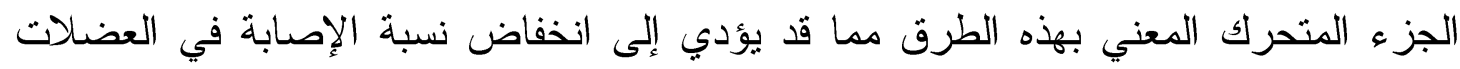
و المفاصل أثثاء عملية الإطالة إلى أب ددى حركي يسمح به الدفصل وفقاً لمنطلبات الأداء

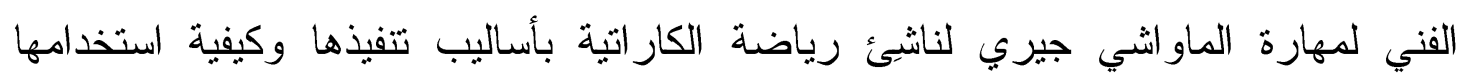
وتوظيفها في البر امج التدريبية.

خاصه بعد التعديلات الجديدة في قانون المباريات و التي تمنح اللاعب ثلاثة نقاط إذا

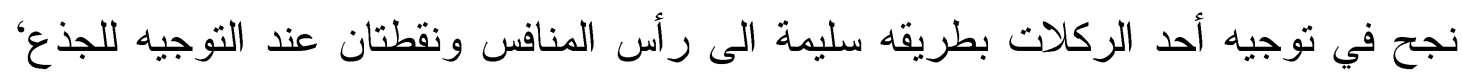




\section{rro}

وبالتالي يمكن للاعب أن يُنهى المبار اة لصالحه باستخدام أحد او بعض الركلات بنجاح ما بين ثلاثة الى أربع مرات خلال المبار اة التي مدتها ثلاثة دقائق، وبذلك يمكن أن تحسم المبار اة مبكرا لمَن يحصل على ثمانية نقاط أولًا مما يؤدى إلى إمكانيه الفوز في أقصر زمن وبأقل جه.

لذلك قام الباحث بإجراء تحليل مباريات بطولة منطقه سوهاج للكار اتية (كومتية)

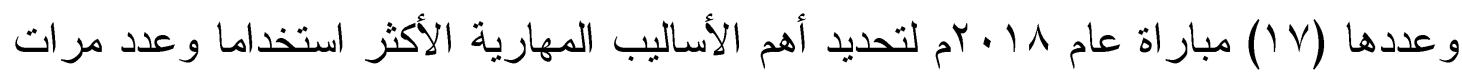
تحقيق الهدف منها ونسبة النجاح المئوية وترتيبها من حيث أكثر استخداما

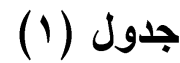

تحليل مباريات بطوله منطقه سوهاج للكار اتية (كومتية)عام 1 ا م ـ بم لتحديد أهم

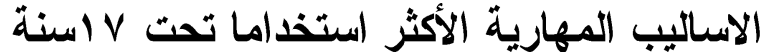

\begin{tabular}{|c|c|c|c|c|}
\hline 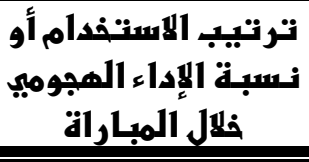 & نالنـانساط & عدد مرات & ع الاستخدرام & المتغيرات قيد الدراسـة الميدانية \\
\hline 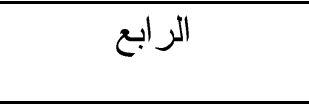 & $\%$ ro & $\mathrm{V}$ & $r$. & كيز امى - سوكي، اللكمية الأمامية القصيرة " Kizami-Zuki " \\
\hline الأول & $\% \varepsilon$. & 10 & ro & جياكو - سوكىي، اللكمية الأمامية المعاكسة " "Gyaku-Zukl ". \\
\hline 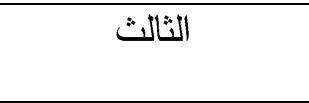 & $\%$ \%.. & $\mathrm{V}$ & 17 & $\begin{array}{c}\text { الركلة الدائرية " ما واشثى جيري } \\
\text { Mawashi - Geri }\end{array}$ \\
\hline 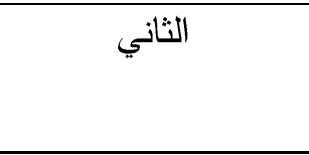 & $\%$ \%. & $\wedge$ & 17 & 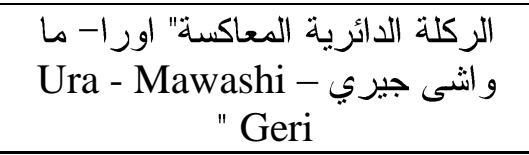 \\
\hline
\end{tabular}

يتضح من جدول (1) أن الأساليب المهارية الأكثر استخداما لدى اللاعبين خلال المباريات التي قام الباحث بتحليلها ببطولة منطقة سوهاج للكار اتيه كوميتة kumite لموسم I 1 ـ لمرحلة تحت V Vنة قد أسفرت عن حصول المتغير الأول اللكمة المستقيمة الأمامية

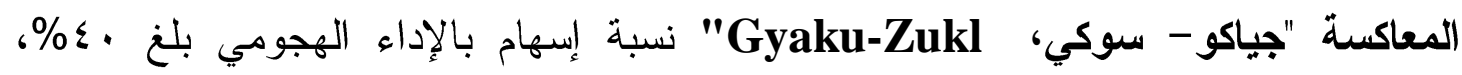
و المتغير الثاني الركلة الائرية المعاكسة" اورا - ما واثى جيري - Ura - Mawashi Geri واشى جيري Mawashi - Geri" نسبة إسهام بالإداء الهجومي بلغ ^.ی \% \%، و المتغير الر ابع اللكمة المستقيمة الأمامية القصيرة "كيزامى - سوكي، Kizami-Zuki" نسبة إسهام

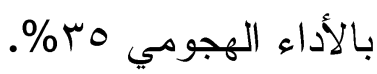
كما قام الباحث بتحليل المراجع و الأبحاث العلمية المرتبطة برياضة الكار اتية وممارسة الباحث لرياضة الكار اتية وعمله كمدرب لرياضة الكار اتية وعمله كأخصائي إصابات ملاعب مجلة أسيوط لعلوم وفنوز التربية الرياضية 


\section{YrY}

وتأهيل بدنى وقيامه بعمل دراسة استطلاعيه بتحليل مباريات بطولة منطقة سو هاج للكار اتية موسم

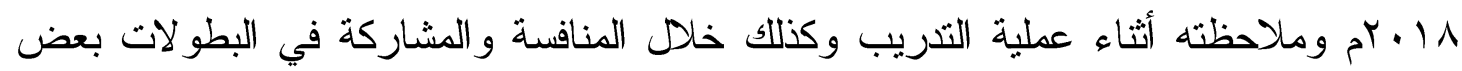
القصور فى مستوى أداء الركلة الدائرية (ماو اشثي جيرب) ويرجع الباحث ذللك إلى بعض قصدور

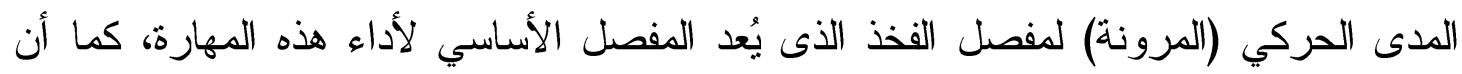

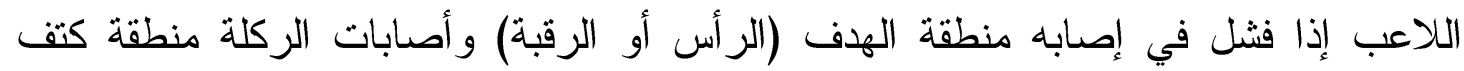

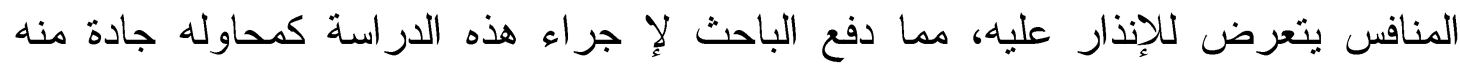

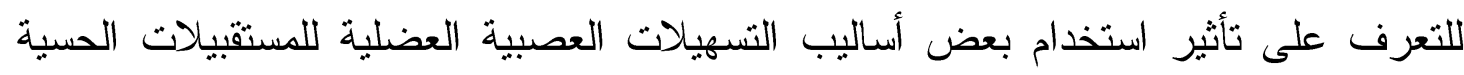
على تحسين الددى الحركي لمفصل الفخذ ومستوى أداء الركلة الدائرية لناشئي الكار اتية.

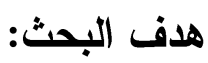

يهدف البحث إلى تحسين مستوى أداء الركلة الدائرية لناشئي الكار اتية من خلال

تصميم برنامج تدريبي باستخدام بعض أساليب التسهيلات العصبية العضلية للمستقبلات الحسية. فروض البحث : - - توجد فروق ذات دلالة إحصائيا بين متوسطات القياس القبلي و البعدي للمجموعة التجريبية لصالح القياس البعدي في مستوى أداء الركلة الدائرية (ماو اثشى جيري) لناشئي الكار انتية.

$$
\text { بعض المصطلحات الواردة في البحث. }
$$

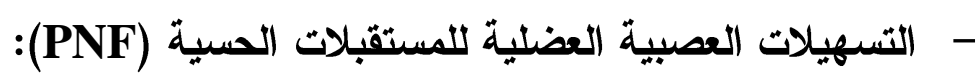

\section{Proprioceptive Neuromuscular Facilitation (PNf)}

هي أحدث طرق تتميه المرونة، وتشمل تمرينات هذه الطريقة على استخدام انقباضات

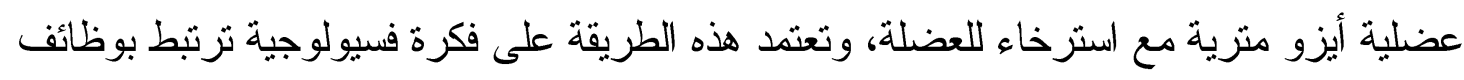

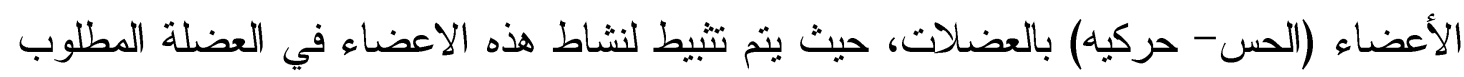

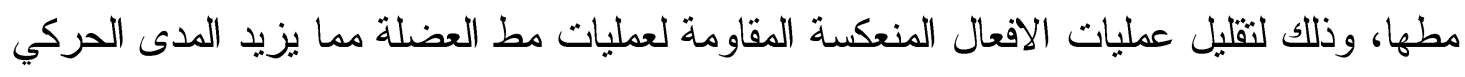

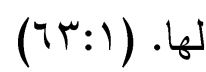

Kicks : الركلات هو فن الهجوم بالقدمين ومنها يستطيع التسديد لمسافات بعيدة. (1:1 ( ) (1) - الركله الائرية: (تعريف اجرائي) هي ركلة هجوميه يتم ادائها بالقدم ومنها يستطيع التسديد لمسافات بعيدة، وتعتبر المرحلة التمهيدية لها هي المرحلة التمهيدية لمعظم الركلات 
إجراعات البحث : البح:

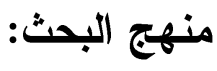

استخدم الباحث المنهج التجريبي لملائمته لطبيعة هذه الدراسة وذلك بتطبيق القياس

القبلي و البعدي كتصميم تجريبي لمجموعة واحدة يطبق عليها البرنامج التدريبي المقترح. مجتمع البحث:

ناشئ الكار اتيه بمركز شباب المدينة بمحافظه سو هاج يشتمل مجتمع البحث على(0)

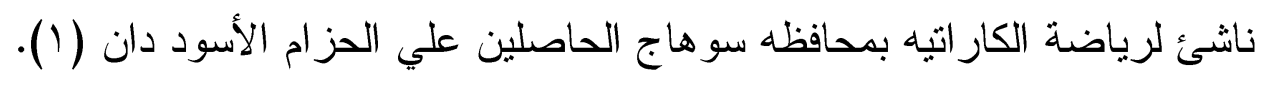
عينة البحث: - ماشئ لرياضة

وقد تم اختيار عينة البحث الكلية بالطريقة العدية وبلغ قوامها (·r) ناشئ لرياضة

الكار اتية وتم تقسيمهم كالتالى : التئل

- - الدجموعة التجريبية وبلغ قو امها(^) ناشئ لرياضه الكار اتية و التي بطبق عليها البرنامج

$$
\text { التدريبي المقتر ح. }
$$

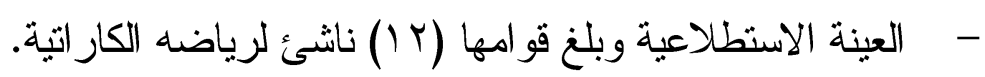

$$
\text { تجانس عينة البحث : }
$$

قام الباحث بإجراء التجانس لأفراد العينة قبد البحث وذلك للتأكد من أن البيانات

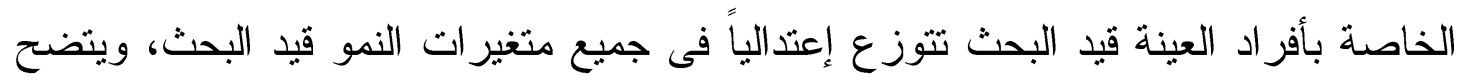

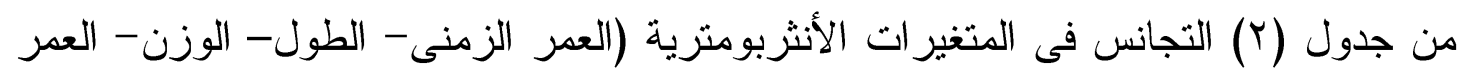
جدول (r)

التدريبى)، و التى قد تئثر على نتائج البحث.

\begin{tabular}{|c|c|c|c|c|c|c|}
\hline 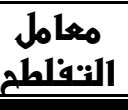 & 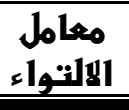 & اللانعياراري & الهسابير & وحدة القياسر & المتغيرات & \\
\hline. YYA- &.$\varepsilon r$ & $.7 \mathrm{~V}$ & $10.1 \mathrm{~V}$ & ل كَقرب ش & السن - ل السن & \\
\hline $1.9 \cdot-$ & $\cdots \pi$ & 0.14 & 17 17.7. & سم & الطول & \\
\hline $1 . r \cdot--$ & $\therefore .10-$ & A. & 01. & كجم ( كم & الوزن & $r$ \\
\hline $1 . \mathrm{r} \varepsilon$ & $. . \wedge 1-$ &.$\wedge r$ & $0 . \mathrm{rV}$ & للأقرب شهر & العمر التدريبي & \\
\hline
\end{tabular}

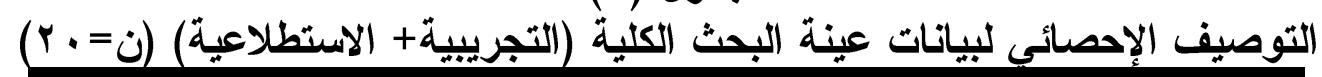

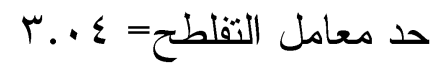

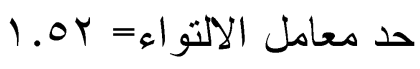

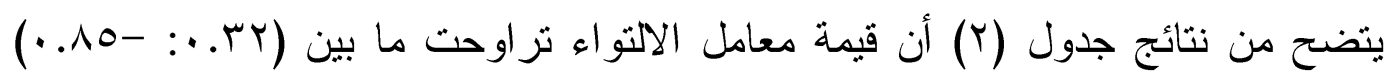

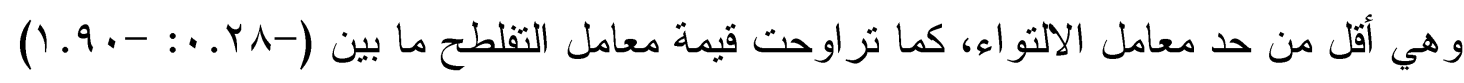

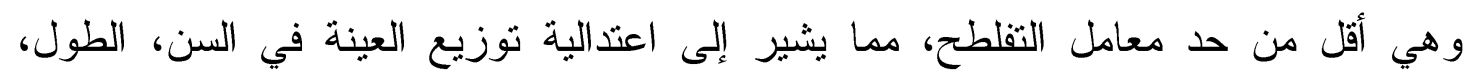

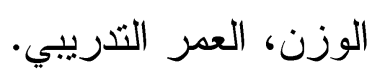




\section{YrA}

أدوات جمع البيانات:

استعان الباحث فى جمع البيانات الخاصة بالبحث بالأدوات والأجهزة التالية :

تحليل المراجع والأبحاث العلمية:

قام الباحث بتحليل المراجع و الدر اسات السابقة في التعرف على الدر اسات التي اهتمت

بأساليب التسهيلات العصبية العضلية للمستقبلات الحسية (PNF) و المتغيرات البدنية و المهارية وكذلك التي تهنم بالبرامج التدريبية وأيضا التي تهنم بدراسة العمل العضلي للمهار ات الرياضية وخاصة في مجال تدريب الكار اتيه.

الملاحظة :

قام الباحث بمتابعة العديد من البر امج التدريبية بنادى شباب المدينة الرياضى وكــللك تحليـلـل بطوله منطقه سو هاج للمرحلة السنية تحت (IV) سنة للموسم بهذف التعرف على أهم المهارات الحركية في رياضه الكار انيه الثائعة لهذه المرحلة هي: ا - الركلة الدائرية " ما و اشى جيري. r- الركلة الدائرية المعاكسة " اورا - ما و اشى جيري. ب- اللكمة المستقيمة الأمامية القصيرة كيز امى سوكي. ع - اللكمة المستقيمة الأمامية المعاكسة " جياكو - سوكي.

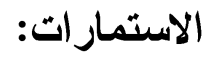

- استماره بأسماء السادة الخبر اء في مجال التدريب الرياضى و الكار اتية مرفق (1) - قام الباحث بتصميم استمارة لتسجيل بيانات أفر اد العينة مرفق (Y) - استمارة استطلاع راى الخبر اء لتحديد اهم اساليب التسهيلات العصبية العضلية للمستقبلات الحسية (pnf) المناسبة للمهارة قيد البحث مرفق (ب) - استمارة استطلاع ر أى الخبر اء لتحديد المحاور و الفترات الزمنية للبرنامج التدريبي المقترح

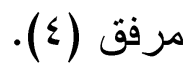
- استمارة دراجات تقييم المراحل الفنية لمهارة الركلة الدائرية اليمني و اليسرى (ماو اشيجيري) مرفق (0). 


\section{rrq}

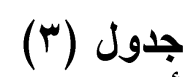

آراء السادة الخبراء في تحديد أنسب أساليب التسهيلات العصبية العضلية للمستقبلات

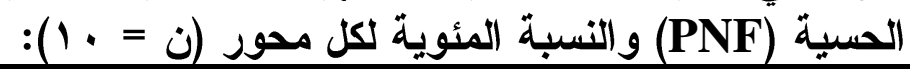

\begin{tabular}{|c|c|c|c|c|}
\hline التر تبب! & النـئية & مجموع أراء & الأسالبب & م \\
\hline 0 & $\% 0$. & 0 & أسلوب الانقباضـات المتكررة & 1 \\
\hline r & $\% \wedge$. & $\Lambda$ & أسلوب البدء الإبقاعي & $r$ \\
\hline$\varepsilon$ & $\% \vee$. & V & أسلوب الانقباض المتبادل البطىى & r \\
\hline 0 & $\%$ & 0 & أسلوب الانقباض المتبادل البطيء مع التثبيت & $\xi$ \\
\hline 0 & $\% 0$. & 0 & أسلوب التثيت بالإيقاع & 0 \\
\hline$r$ & $\% 9$. & 9 & أسلوب الانقباض - الارتخاء & 7 \\
\hline 1 & $\% 1 \ldots$ & 1. & أسلوب التثيت - الارتخاء & V \\
\hline 1 & $\% 1 \ldots$ & $1 \cdot$ & أسلوب التثبيت- الارتخاء مع انقباض & $\Lambda$ \\
\hline$\varepsilon$ & $\% \vee$. & V & أسلوب الانقباض - الارتخاء - الإطالة & 9 \\
\hline
\end{tabular}

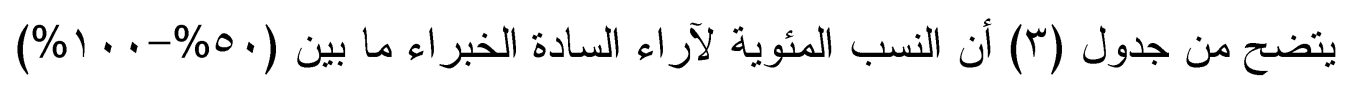

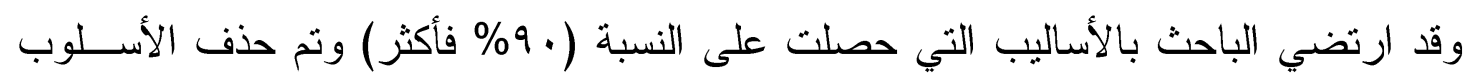

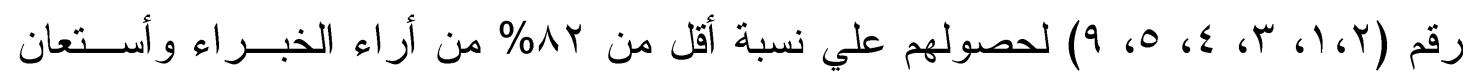

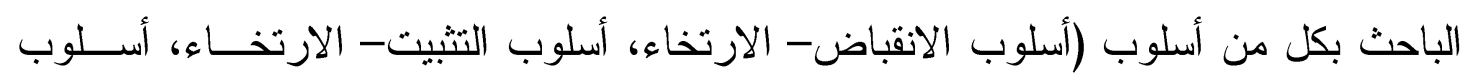
التثبيث- الارتخاء مع انقباض العضلات المحركة) في البرنامج التدريبي المقترح.

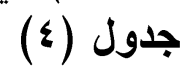

آراء السادة الخبراء في تحديد محاور البرنامج التدريبي المقترح و النسبة المئوية لكل محور (الن

\begin{tabular}{|c|c|c|c|}
\hline 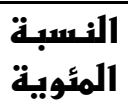 & مجموع أراء & المهـاور & م \\
\hline$\overline{\% 1 \ldots}$ & $\overline{1 .}$ & فترة البرنامج التدريبي المقترح ثمانية أسابيع (شهرين) & $\overline{11}$ \\
\hline$\% 9$. & 9 & عدد الوحدات التدرييية في الأسبو ع (ع) وحدات. & r \\
\hline$\% 1 \ldots$ & 1 . & زمن الوحدة التدرييية (.9) دقيقة. & $r$ \\
\hline$\% 1 \ldots$ & 1. & 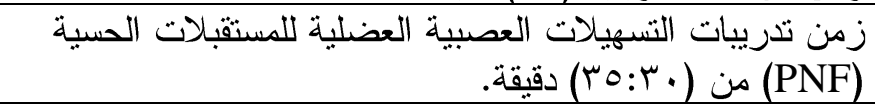 & $\varepsilon$ \\
\hline$\% 1 \ldots$ & 1 . & تطبيق تدريبات التسيهيلات العصبية العضلية للمستقبلات الحسية الجئية & o \\
\hline$\% 9$. & 9 & لدورة الحمل الأسبو عبة (Y:1). & 7 \\
\hline
\end{tabular}

يتضح من جدول (ع) الفترات الزمنية والنسبة المئوية لآر اء السادة الخبر اء حول محاور

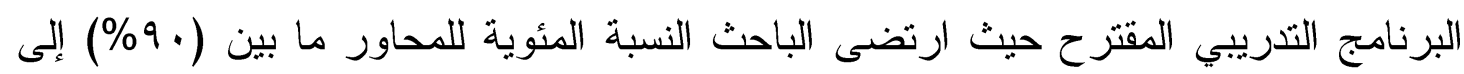
(\%) (...) مجلة أسيوط لعلوم وفنون التربية الرياضية 


\section{rr.}

تقييم مستوي الأداء المهاري للركلة: - تقييم مستوي أداء مهارة الركلة الائرية (ماو اثيـ- جيري) اليمني واليسرى مرفق (†):

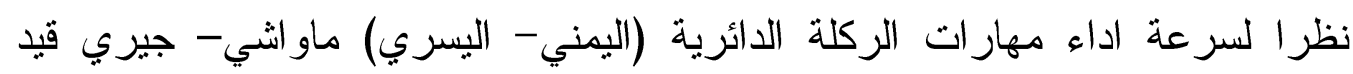
البحث تشكل صعوبة في تقييم مر احلها وزمن أدائها بطريقة الملاحظة العادية، لذا استخدم

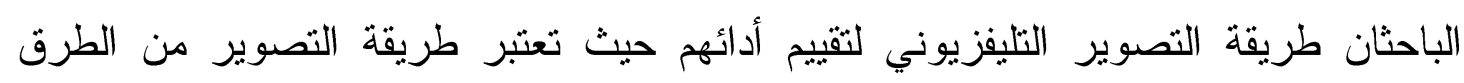
الحديثة نسبيا وموضو عية للتقييم ثاتياً: الأجهزة والأدوات نات المستخدمة: قام الباحث بتحديد الأدوات والأجهزة التي تستخدم على عينة البحث في تتفيذ إجراءات البحث للحصول على البيانات المراد الحصول عليها. أجهزة وأدوات القياسات والاختبارات الجسمية وتضمن : - مقياس طول Restmeter لقياس طول اللاعب الكلى لأقرب (سم). - ميزان طبى لقياس الوزن لأقرب (كجم).

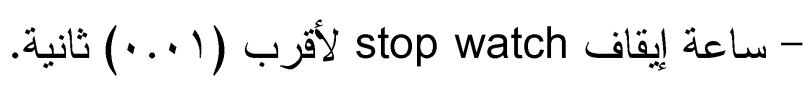

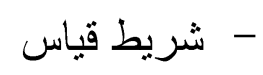
أجهزه وأدوات التصوير : - كامير ا تصوير تليفزيوني (كامير ا فيديو). - و احد حامل ثلاثي لآلة التصوير - وصله كهربائية - شاشـة عرض تليفزيوني. المعاملات العلمية المستخدمة فى البحث:

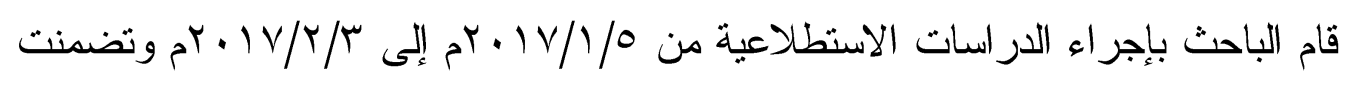

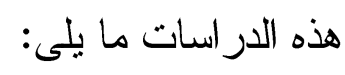
الار اسة الاستطلاعية الاولي:

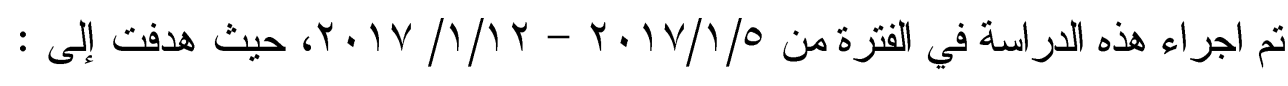

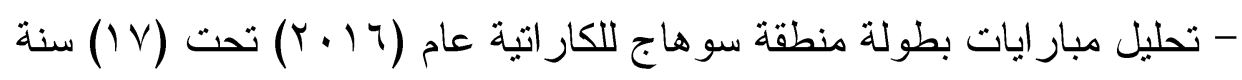

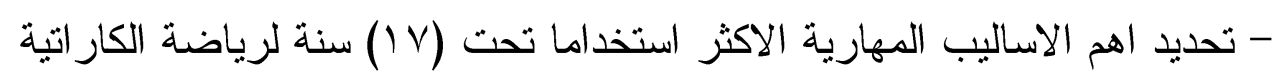
نتائج هذه الدر اسةة: تم تحديد اهم الاساليب المهارية الاكثر استخداما تحت (V V) سنة وهي: 


\section{rM}

Kizami-Zuki اللكمة المستقيمة الأمامية القصيرة " كيز امى - سوكية - اللكمة المستقيمة الأمامية المعاكسة " جياكو - سوكي" - الركلة الدائرية " ما واثى جيري" Mawashi - Geri -

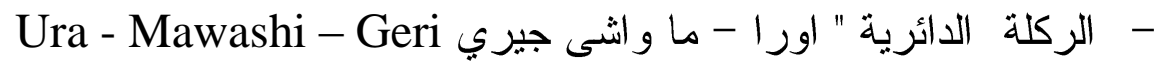

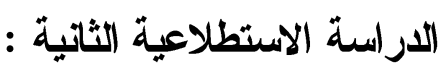

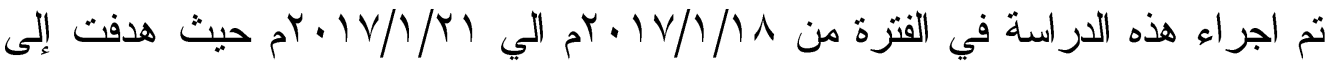

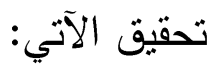
- - التأكد من صلاحية الصالة المغطاة المطبق بها تجربة البحث من حيث التهوية والإضاءة

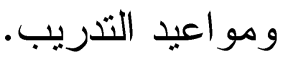
- - التأكد من صلاحية الأجهزة و الأدوات المستخدمة قبد البحث.

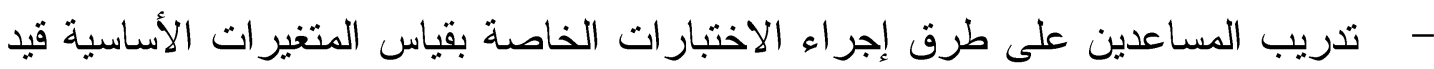
البحث.

- - - التعرف علي مدي مناسبة التمرينات وتقنيين الأحمال و الزمن المستغرق لكل تمرين. - - مترتيب التمرينات وفق درجة صعوبتها. - - التعرف علي نواحي القصور التي قد تحدث من اجل العمل علي تلاشيها أثناء تتفيذ

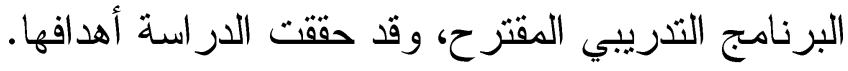

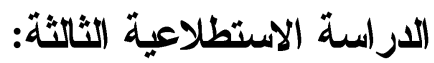

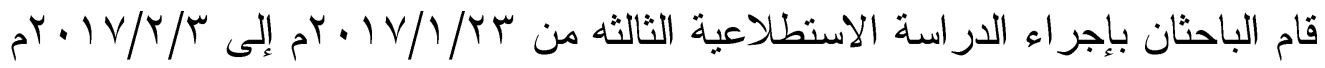

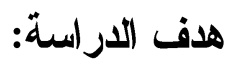
- اجراء المعاملات العلمية للاختبارات قيد البحث المعاملات العلمية للاختبارات قيد البحث

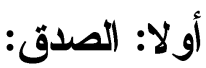

قام الباحث باستخدام صدق التمايز عن طريق إيجاد الفروق بين مجموعتين إحداهما

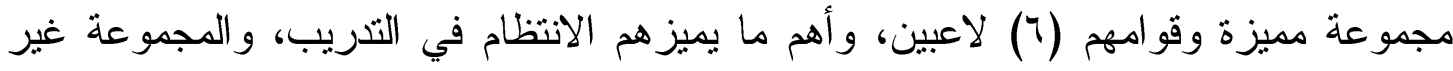

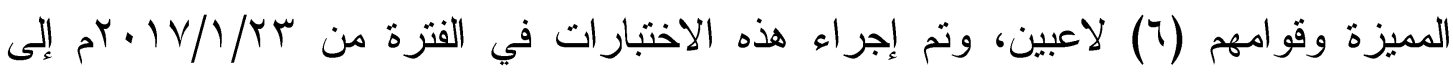

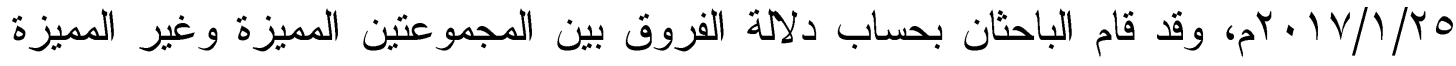

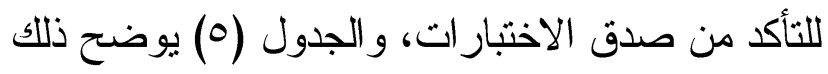




\section{rrr}

جدول (0)

الفرق بين متوسطات درجات المجموعتين المميزة وغير المميزة في الاختبار المهارى قيد البحث $(1 r=\dot{0})$

\begin{tabular}{|c|c|c|c|c|c|c|c|c|}
\hline \multirow{2}{*}{ الدلاستوبي } & \multirow{2}{*}{$\begin{array}{l}\text { قيهمة } \\
\text { (ت) }\end{array}$} & \multicolumn{2}{|c|}{ المجموز عة غيرة } & \multicolumn{2}{|c|}{ المجمو عة المهيزة ز = } & \multirow{2}{*}{ القياسة وهدة } & \multirow{2}{*}{ الهتغـيرات } & \multirow{2}{*}{ م } \\
\hline & & المعياريدي & المتوسيط ابمي & الالهعيارياف & المسيابـي & & & \\
\hline دال & T.ro & $0 . \mu \wedge$ & 1.71 & 7.91 & $1 . V r$ & سم & (الركلة الدائرية & \\
\hline دال & $11 \ldots$ & $1 . V Y$ & $1.7 r$ & $1 . V T$ & 1.70 & سم & (الركلة الدائرية & المهاري \\
\hline
\end{tabular}

يتضح من جدول (0) وجود فروق دالة إحصائيا بين المجموعتين المميزة وغير

المميزة في منوسط درجات الاختبار المهارى لصالح المجموعة المميزة حيث نزاوحت قيمة "ت" المحسوبة ما بين (0. . - . . .11) في اختبار الأداء المهارى للركلة الدائرية وهي أكبر من قيمة (ت) الجدولية عند مستوى معنوية "ه . . ". ثانياً: : معامل الثبات

لإيجاد معامل الثبات للاختبار ات قبد البحث استخدم الباحثان طريقة تطبيق الاختبار و إعادة تطبيقه على عينة قو امها(T) من مجتمع البحث وخارج عينة البحث الأساسية و الذين

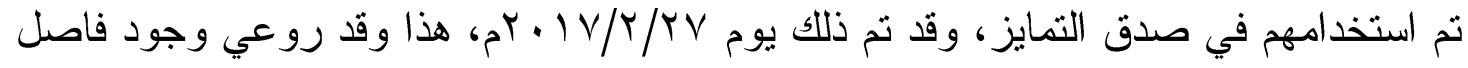
زمني بين التطبيقين قدره سبعة أيام، وقد تم إيجاد معامل الارتباط بين التطبيقين باستخدام جدول (7) معادلة بيرسون وجدول (T) يوضح ذلك. معامل الارتباط بين التطبيقين الأول والثاني للاختبار

\begin{tabular}{|c|c|c|c|c|c|c|c|c|}
\hline \multirow{2}{*}{ مالدالتوي } & \multirow{2}{*}{ قيمة } & \multicolumn{2}{|c|}{ التطبيجز الثنانـي } & \multicolumn{2}{|c|}{ التطبية الأول } & \multirow{2}{*}{ القياسرة وهشر } & \multirow[b]{2}{*}{ المتغهيرات } & \\
\hline & & المعياريري & المتوسابي & الالنهيارياف & المستوسي & & & \\
\hline دال & *..V4T & 9.10 & 1.79 & 7.91 & $1 . V Y$ & سم & الركلة الدائرية اليمني & \multirow[t]{2}{*}{ المهاري } \\
\hline دال & $* .091$ & r.17 & 1.70 & $1 . V Y$ & 1.70 & سم & الركلة الدائرية اليسرى & \\
\hline
\end{tabular}

دال * - n قيمة (ر) الجدولية عند مستوى دلالة (0. . .) = مجلة أسيوط لعلوم وفنوز التربية الرياضية 


\section{rrr}

يتضح من جدول (ا) وجود ارتباط دال إحصائيا بين التطبيقين الأول والثاني في

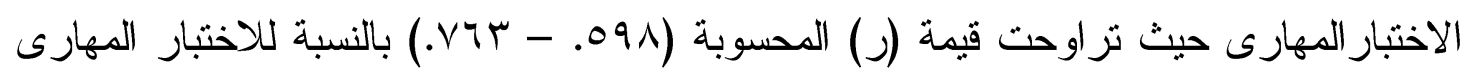

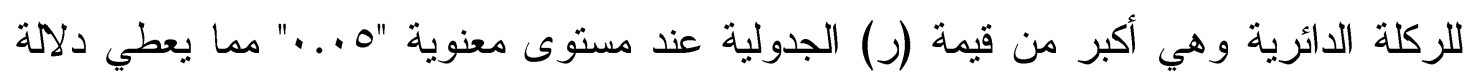
مباشرة على ثبات الاختبار ات قيد البحث.

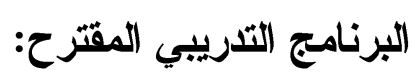

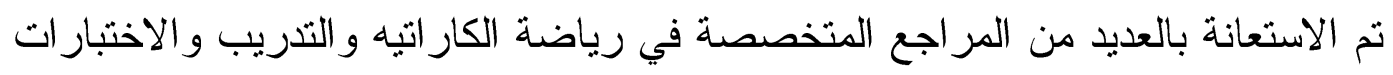

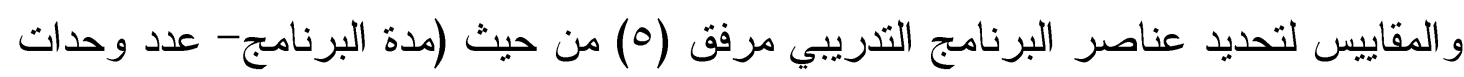

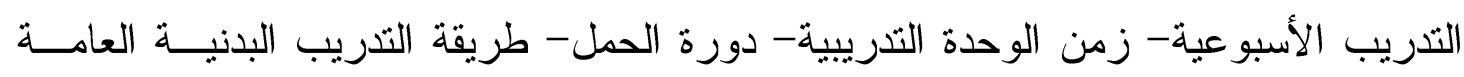

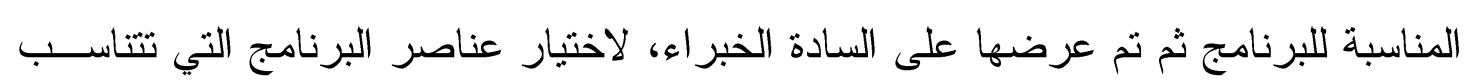

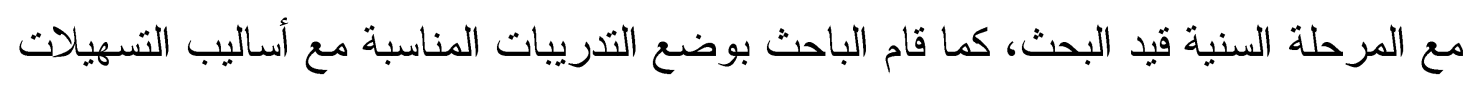

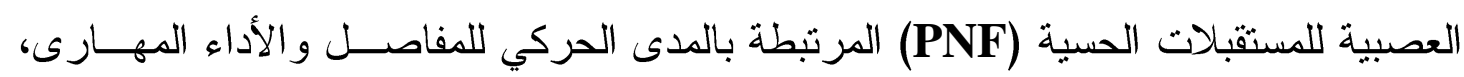
وذلك من خلال:

- - تحديد العضلات و المفاصل العاملة في المهارة قيد البحث من خلال تحليل المر اجع العلمية.

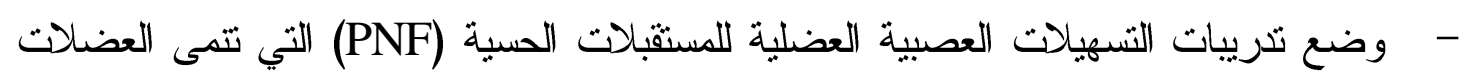

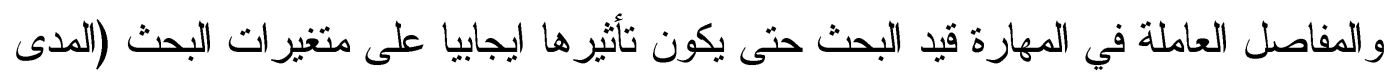
الحركي لمفصل الفذذ- مهار اي) من خلا لحل تحليل المراجع العلمية. - - تطبيق بعض التنريبات على العينة لمعرفة تقنين حمل التدريب.

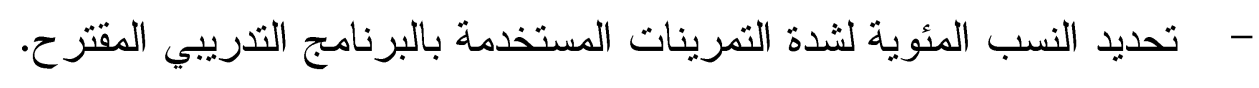

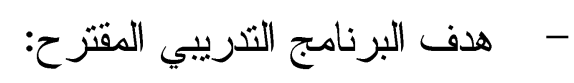
يهدف البرنامج التدريبي المقترح إلى محاولة تحسين مستوي أداء الركلة الدائرية (ماو اشي- جيري). - أسس وضع البرنامج التدريبي المقترح :

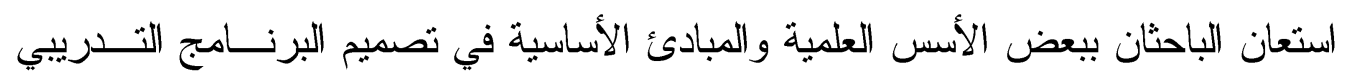

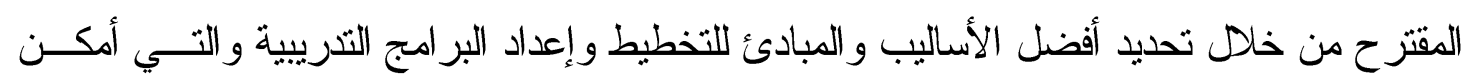

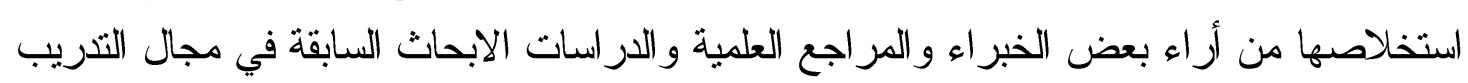

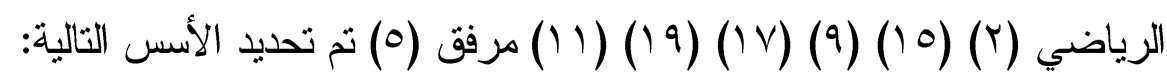
- مر اعاة مبدأ الفروق الفردية بين أفراد العينة في المرونة. 


\section{rre}

- - التدرج في التمرينات من السهل إلي الصعب ومن البسيط إلي المركب مع التدرج في

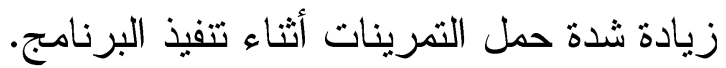

- - مر اعاة الخصائص الفسيولوجية و الحركية للمرحلة السنية لأفر اد العينة قيد البحث. - مراعاة أن تبدأ التدريبات الخاصة لـPNF بالمجموعات العضلية الكبيرة يليها

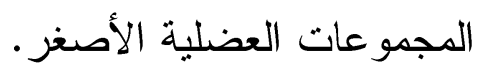
- استخدام الطريقة الموجية في تشكيل شدة حمل التذريبات وعدم استخدام طريقة ثابتة في شدة الحمل (r: (1). - - تطبيق البرنامج التدريبي المقترح بطريقة التدريب الفتري (منخفض - ومرتفع) الثدة.

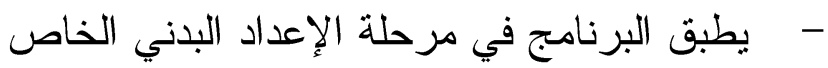

توزيع زمن البرنامج التّريبي المقترح:

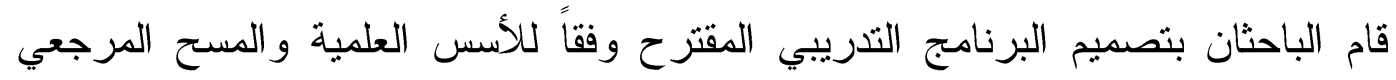

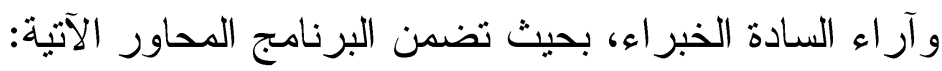
تحديد الفترة الزمنية للبرنامج التدريبي:

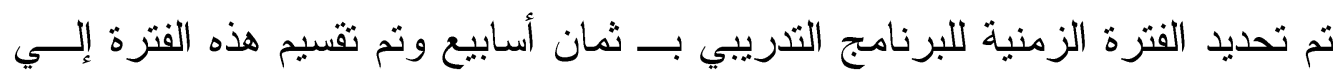

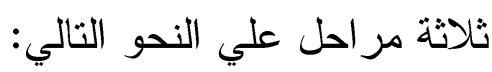

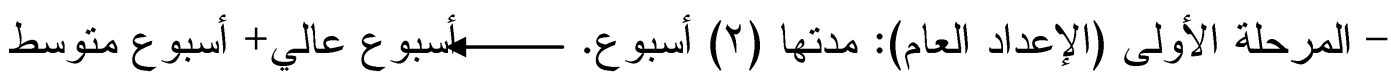

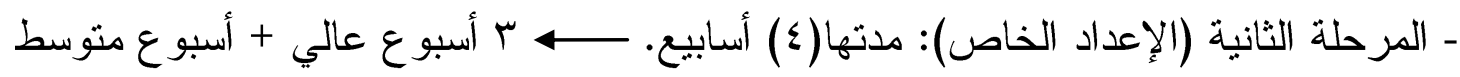

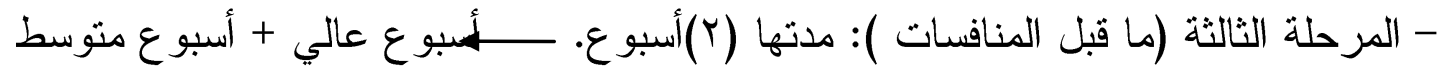
تصليد عدد الوحدات التدريبية خلال البرنامج التدريبي: التهات

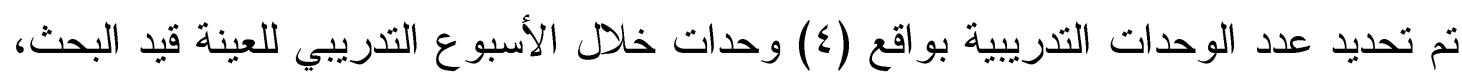

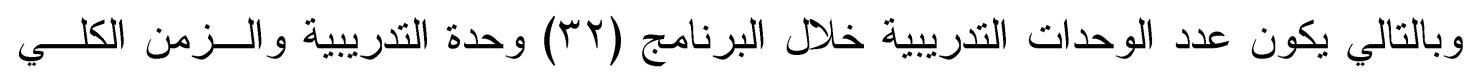

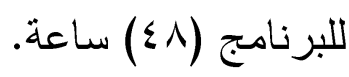
تحليد زمن الوحدة التدريبية :

- زمن الوحدة التدريبية الكلية= ، و دقبقة

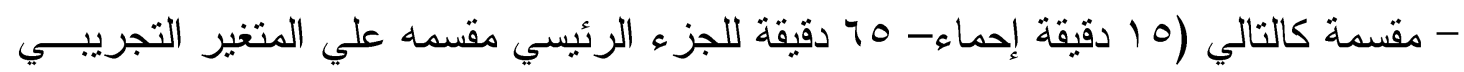
و و الجزء المهارى - - (1 دقائق ختام).

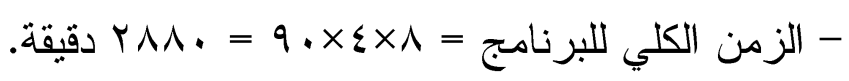

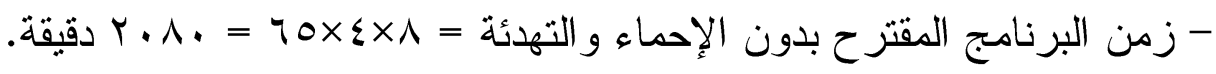




\section{rro}

- قام أفر اد العينة قيد البحث بتطبيق البرنامج التدريبي المقترح بطريقة التـدريب المفتـري (منخفض - ومرتفع) الثدة

تمرينات الإحماء:

تم تحديد زمن تمرينات الإحماء (0 10) دقيقة ويؤديه جميع أفر اد العينة قيد البحث وذلك

لتهيئة الجهازين الدوري و التتفسي مع التركيز علي تمرينات الإطالة والمرونة.

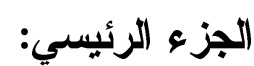

تم تحديد زمن الجرعة الرئيسية (10) دقيقة ، وفي هذا الجزء يتم تقسـيم تـدريبات

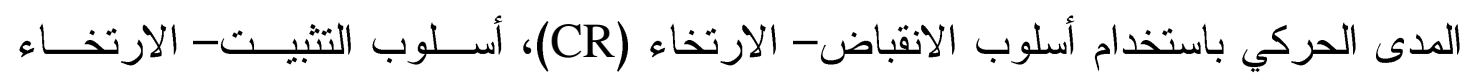
(HRAC) (أسلوب التبييت- الارتخاء مع انقباض العضلات المحركة ) علي المفصل العامل للمهارة قيد البحث بالإضافة إلي مجموعة من التدريبات المهارة التي تســتخدم فــي

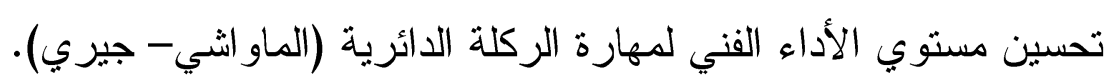

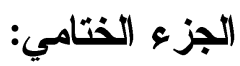

تم تحديد زمن تمرينات الختام بــــ ( () دقائق وهي عبارة عن تمرينات للاسترخاء و التي

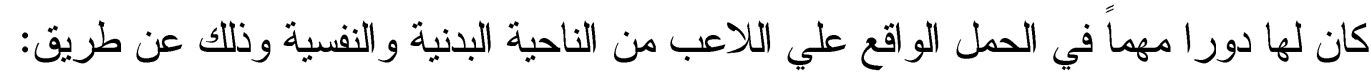
- تمرينات تهدئة اللاعبين و العودة بهم لحالة الاستشفاء. - تمرينات المرونة الايجابية و السلبية.

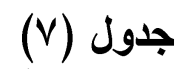

النسب المئوية المستخدمة لارجات الحمل

\begin{tabular}{|c|c|}
\hline النسبب المئوبة & درجات الحمل \\
\hline 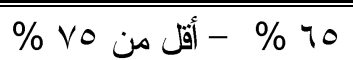 & متوسط \\
\hline 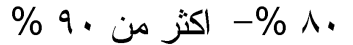 & عالى \\
\hline
\end{tabular}

يوضح الجدول رقم (V) درجات حمل التدريب للتمرينات باستخدام زمن الحد الأقصى

لأداء التمرين ثم حساب درجات الثدة المختلفة عن طريق معادلة خاصة بالكثافة النسبية

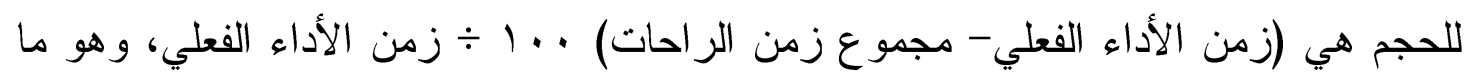
تم استخدامه في الوحدات التذريبية. نموذج للتوزيع زمن تدريب مهارة الركلة الدائرية (ماو اشي- جيري) على الاعدادات

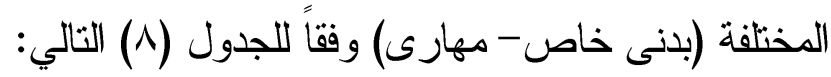




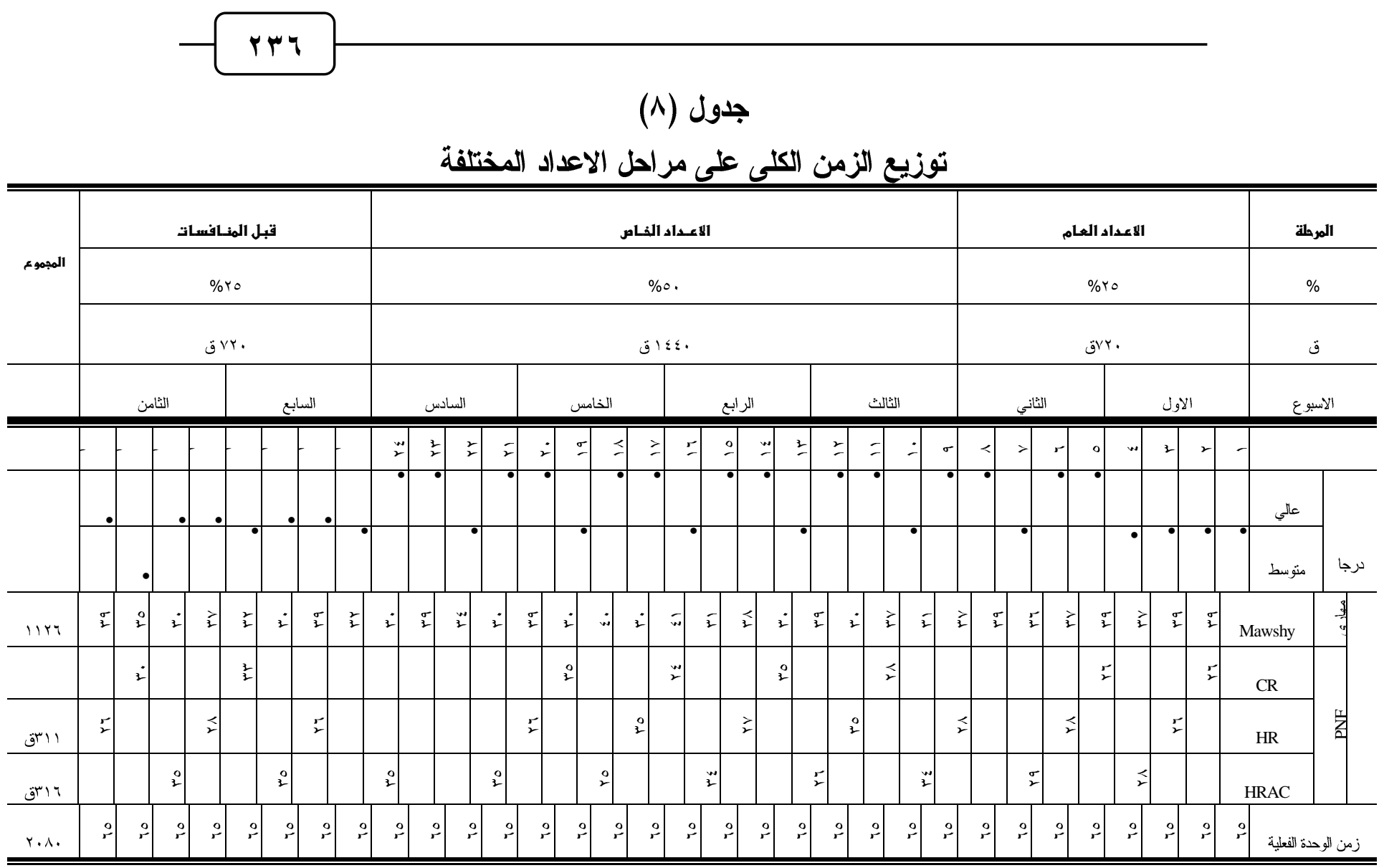

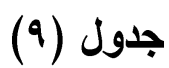

الخطة الكلية للبرنامج

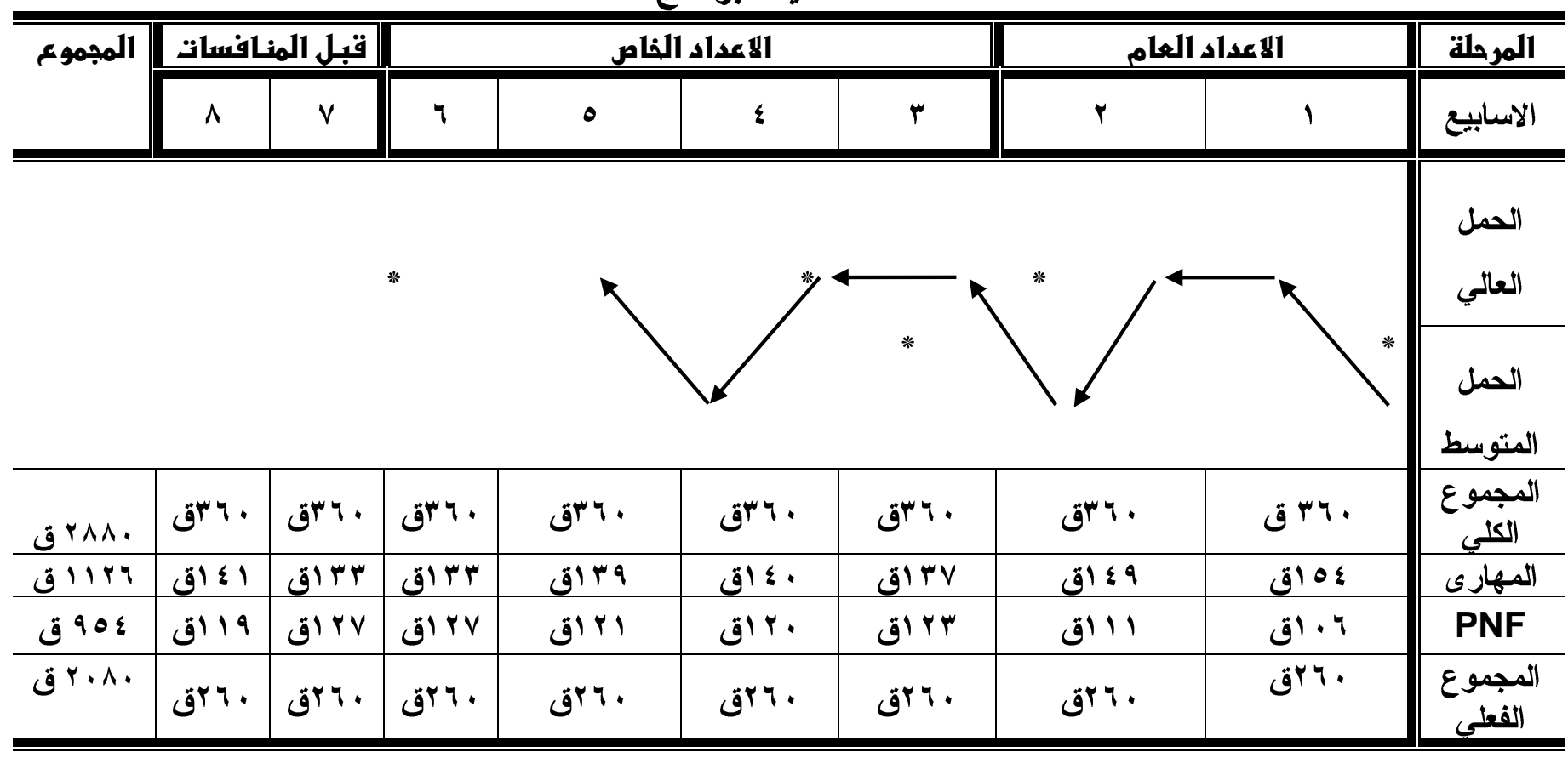




\section{rrv}

جلول (1. (1)

التوزيع الزمني الاسبيوعي للوحدات التدريبية (1)

\begin{tabular}{|c|c|c|c|c|c|c|c|c|c|c|c|c|c|}
\hline \multicolumn{3}{|c|}{ الذميسر } & \multicolumn{3}{|c|}{ الاربعاء } & \multicolumn{3}{|c|}{ الاثنيرن } & \multicolumn{3}{|c|}{ السبت } & \multicolumn{2}{|c|}{ 1الايام } \\
\hline الوهدة & الهمارى & PNF & 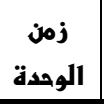 & الهمارى & PNF & | الومدة & الههارى & PNF & الوهدة & المهارى & PNF & والدقائزة & الاسابير \\
\hline סT0ق & $\% \uparrow$ & $\% \varepsilon$. & סףق & $\% 04$ & $\% \leq \leqslant$ & Tro & $\% ч$. & $\%$ \%. & & $\%$ \% & $\% \varepsilon$. & $\%$ & \multirow{2}{*}{1} \\
\hline ماتق & 9rق & 4ra & مبق & VIT & دזق & ق90 & 9rق & צrG & ס7ق & 9"اق & צrق & ق & \\
\hline 0باق & $\% \circ 4$ & $\% \leq \leq$ & ماكق & $\%$ \%. & $\% \varepsilon$. & & $\% \circ 0$ & $\% \leq 0$ & 07ق & $\% 04$ & $\% \leq \varepsilon$ & $\%$ & \multirow{2}{*}{ r } \\
\hline ماق & VIT & גזق & هبق & 9rق & דז' & & דساق & 9rق & סדق & rاق & هبق & ق & \\
\hline סاق & $\% 4$. & $\% \varepsilon$. & סاق & $\%$ \& & $\% 00$ & & $\% 04$ & $\% \leq \leqslant$ & סדق & $\% \leqslant v$ & $\% \circ r$ & $\%$ & \multirow{2}{*}{$r$} \\
\hline סדتق & 9"و & דrق & סاق & . & סro & & ق & גזق & 070 & آبق & ع זوق & ق & \\
\hline هاق & \%тr & $\% r v$ & هبق & $\%$ \% V & $\% \circ r$ & & $\% \circ v$ & $\% \leq r$ & هاق & $\% \varepsilon 0$ & $\% \circ 0$ & $\%$ & \multirow{2}{*}{$\varepsilon$} \\
\hline & 1 & ع & סاق & است & ع بق & & دساق & VT & סדق & • بق & סחق & ق & \\
\hline ס10 & $\%$ ६ & $\%$ & סاق & $\% ч$ & $\% \varepsilon$ & 010 & $\% 01$ & $\% \leq 9$ & 07ق & $\% \leqslant 0$ & $\% \Delta 0$ & $\%$ & \multirow{2}{*}{0} \\
\hline OTlo & . & סrق & هبق & 9rق & דזق & م70 & ع بق & اسق & סדق & •rق & סrاق & ق & \\
\hline مانق & $\% 4$ & $\% \varepsilon$ & هبق & $\% \leq 0$ & $\% \circ 0$ & & \% Tr & $\%$ \% & 07ق & $\% \leqslant 0$ & $\% \circ 0$ & $\%$ & \multirow{2}{*}{7} \\
\hline هبق & 9rق & דזق & هبق & . rق & סri & & . كق & סצق & סדق & . & סזق & ق & \\
\hline Oباق & $\%$ \% & $\%$ or & مباق & $\%$ \% & $\% \circ 0$ & ق90 & $\%$ \%. & $\%$. & 07ق & $\%$ \% & $\%$ or & $\%$ & \multirow{2}{*}{$v$} \\
\hline هبق & rra & זrق & مان & .r". & סمبق & مان & 9ra & צופ & 07ق & rra & rr|ق & ق & \\
\hline 0بق & $\%$ \% & $\% \varepsilon$ & مبق & $\% 00$ & $\%$ ६ & ق70 & $\%$ or & $\%$ \% & סזق & $\% 04$ & $\%$ « & $\%$ & \multirow{2}{*}{$\wedge$} \\
\hline סדق & qra & דזق & סجق & oro & r. & م70 & rra & זسق & סדق & v vaق & ג'ق & ق & \\
\hline 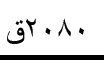 & Vو זق & ع זrق & - & 19ו & 9 & - & rare & & - & 4rופ & كوبق & \multicolumn{2}{|c|}{ المجموع } \\
\hline
\end{tabular}

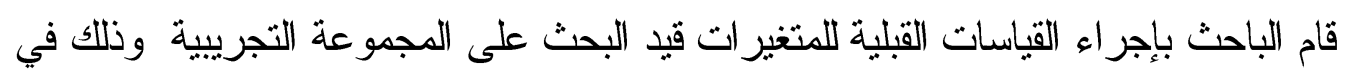

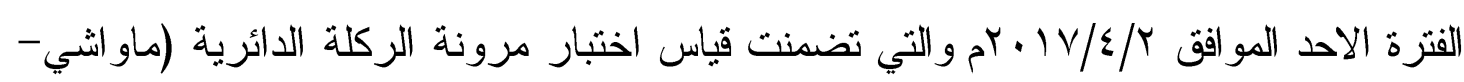

$$
\text { جيري) اليمني و اليسرى. }
$$

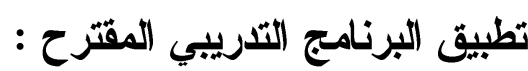

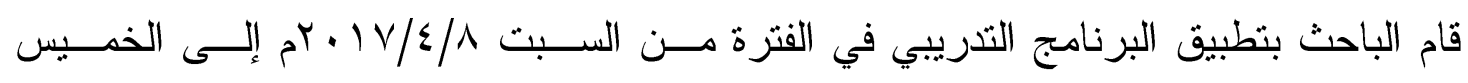

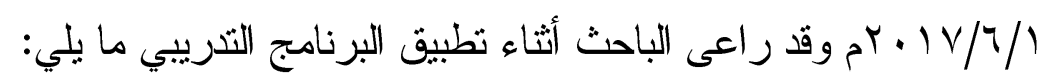
إجراء القياسات البعدية:

بعد الانتهاء من تطبيق البرنامج التدريبي قام الباحث بإجر اء القياسات البعدية على البى

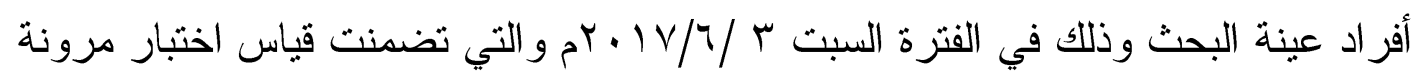

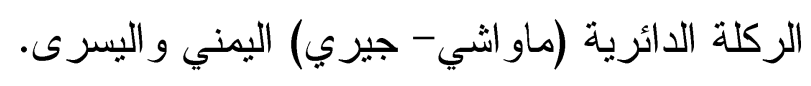

مجلة أسيوط لعلوم وفنوز التربية الرياضية 


\section{rrA}

المعالجات الإحصائية المستخدمة:

لطبيعة البحث و أهدافه استخدم الباحث المعالجات الإحصائية التالية.

$$
\text { - الانحر اف المعياري. }
$$

- اختبار (T. Test) لدلالة الفروق الإحصائية.

- النسبة المئوية. - معامل التقلطح.

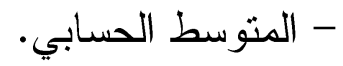

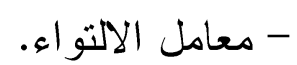

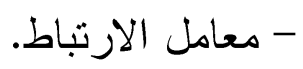

عرض ومناقشة النتائج :

أولاً : عرض أنت ومنائه :

توجد فروق ذات دلاله إحصائيا بين منوسطات القياس القبلي والبعدي للمجموعة التجريبية لصالح القياس البعدي في مستوى أداء الركلة الدائرية (ماواشى جيري) لناشئي

\section{جدول (11)}

دلاية الفروق بين متوسطي درجات القياسين القبلي والبعدي لعينه البحث في مستوي الأداء

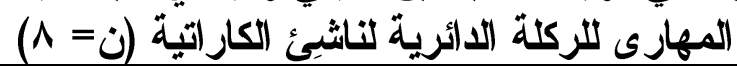

\begin{tabular}{|c|c|c|c|c|c|c|c|c|}
\hline \multirow[b]{2}{*}{ التحسبةز } & \multirow[b]{2}{*}{ مالدالةوك } & \multirow[b]{2}{*}{$\begin{array}{l}\text { قيمة } \\
\text { (ت) }\end{array}$} & \multicolumn{2}{|c|}{ القياسر البعدي } & \multicolumn{2}{|c|}{ القياس القبلي } & \multirow[b]{2}{*}{ القياسر وحدة } & \multirow[b]{2}{*}{ المتغهيرات } \\
\hline & & & المعبياري إذي & المتوس & المعياري الانـراذ & المتوابي & & \\
\hline \%or.o & 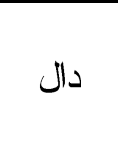 & $1 V .7$ & $1 . r$. & $1 . V r$ & $1 .+7$ & 1.71 & سم & اليمني (ماو الثية الدية \\
\hline$\mu \cdot .\{\Lambda$ & 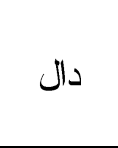 & 17.10 & 0.9 . & 1.79 & V.l. & $1.7 \varepsilon$ & سم & اليسري (ماو الثية الدئية \\
\hline
\end{tabular}

נ)*

قيمه (ت) عند مستوي دلالة (0. . ) =

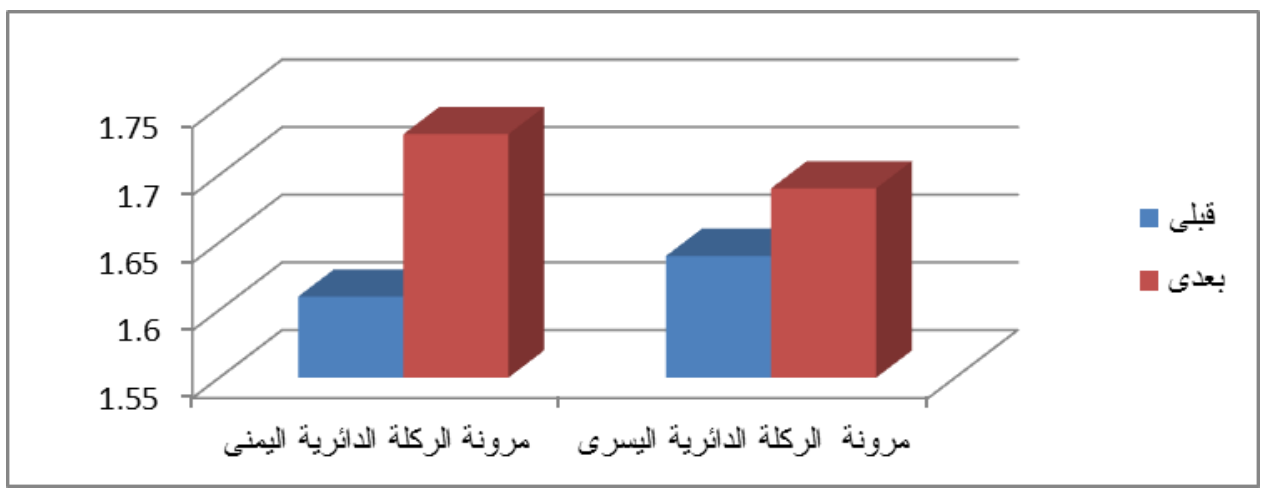

شكل (1) فروق المتوسطات بين القياسين القبلي و البعدي للأداء المهارى للعينة قيد البحث 


\section{rrq}

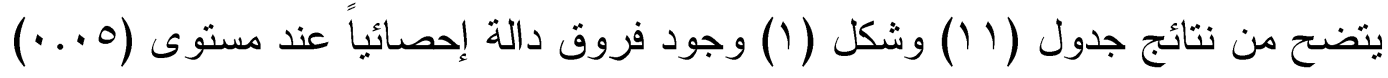

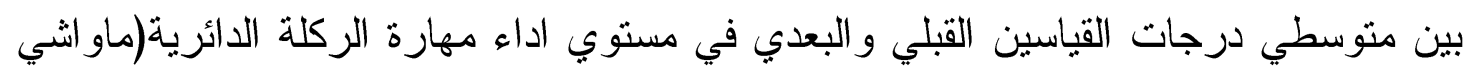

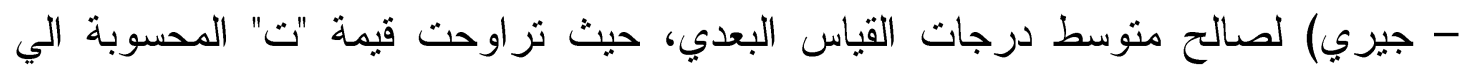

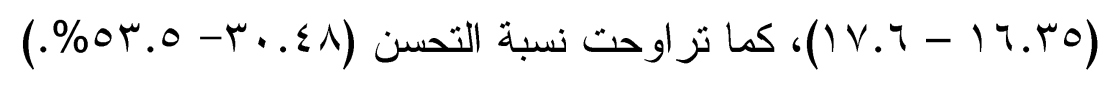

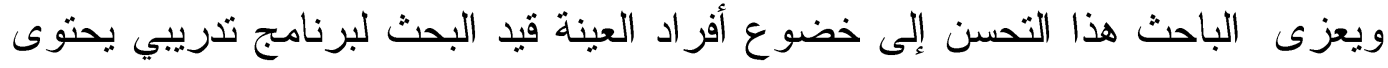

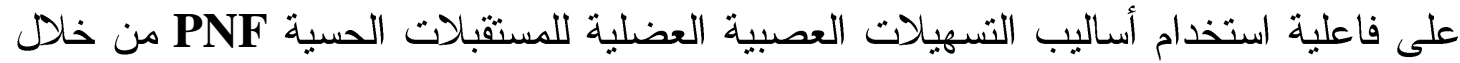

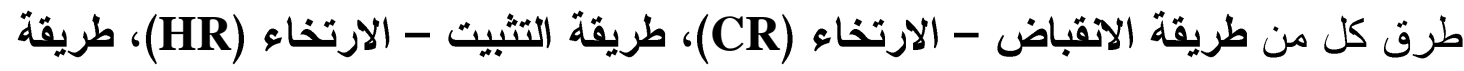

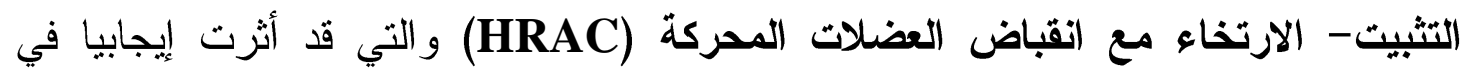

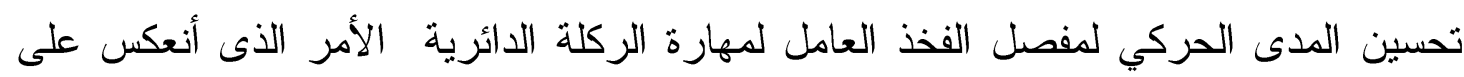

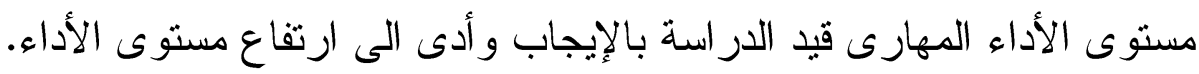

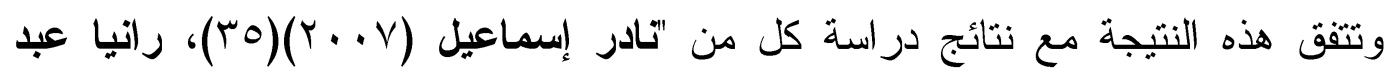

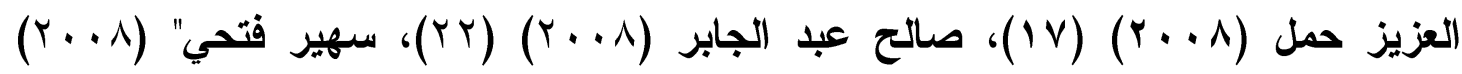

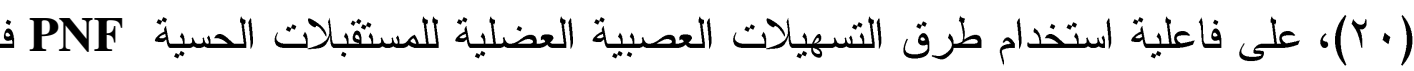
تحسين مستوى الأداء الحركي لاي الرياضيين. ويشير "محمد حسن علاوى" (199V) أن ضعف مستوى المرونة الادين عند الرياضيين يؤثر

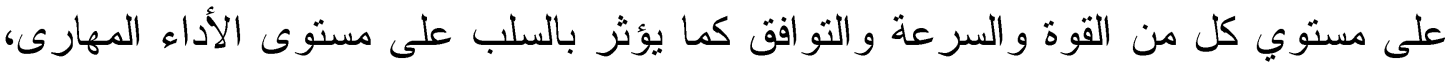

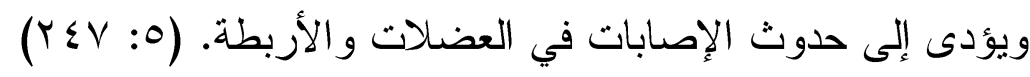

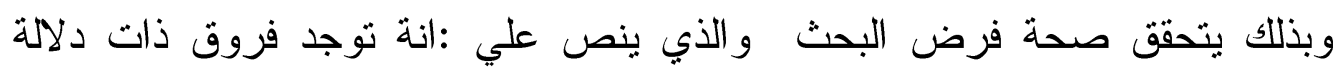

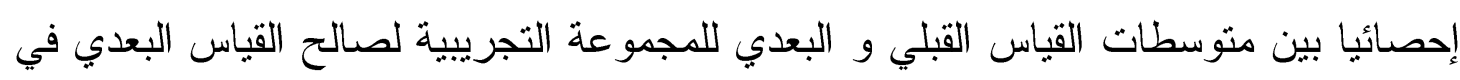
مستوى أداء الركلة الدائرية (ماو اشیى جيري) لناشئي الفئي الكار انيه.

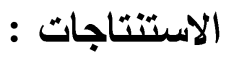

- - أن تدريبات التسهيلات العصبية العضلية ذو فاعلية ايجابية لتحسين مستوي الركلة الدائرية

$$
\text { (مواشي - جيري) لاي ناشئ الكار اتية. }
$$

في ضوء أهداف البحث ونتائجه وفى حدود العينة، يوصى الباحث بما يلى:

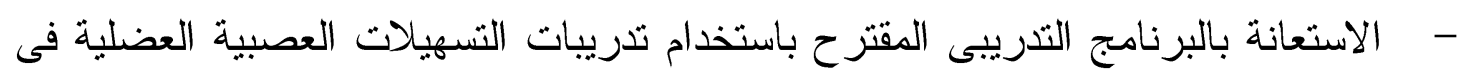
العملية التدريبية فى رياضة الكار اتية.

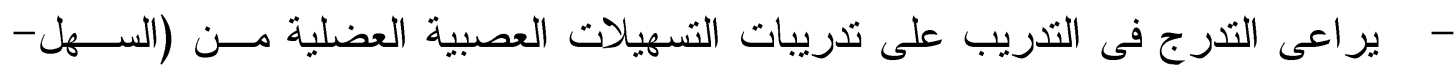

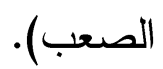




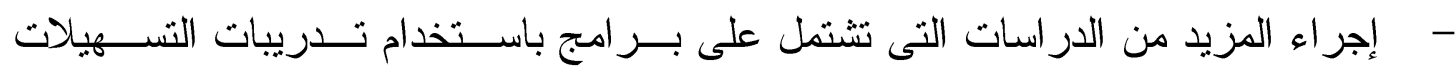

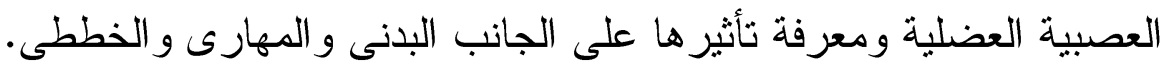

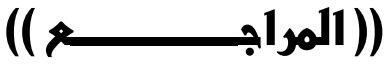

\section{أولا : المراجه العربية}

1- أبو العلا أحمد، أحمد نصر الدين بهو 9 ام: "فسيولوجيا اللياقة البدنية" دار الفكر العربي، القاهرة.

r- أحمد محمود (براهيم (1991)

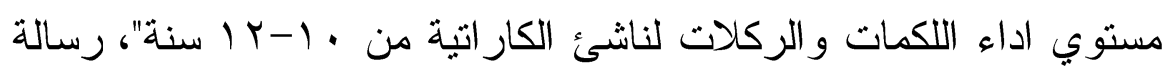
دكتور اه، كلية التربية الرياضية، جامعة الاسكندرية.

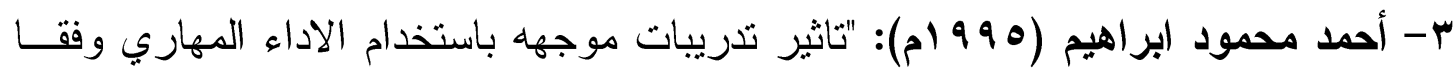

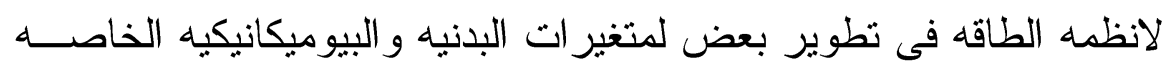

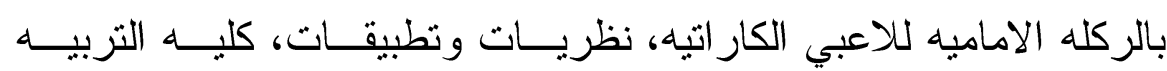
الرياضيه، جامعه الاسكندريه ،العدد الو احد و العشرون..

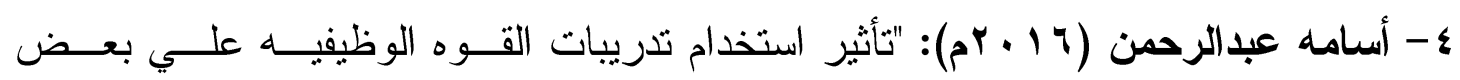

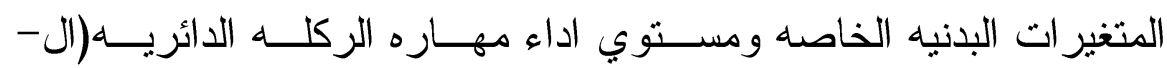

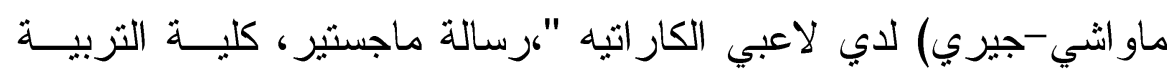

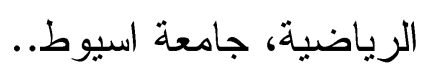

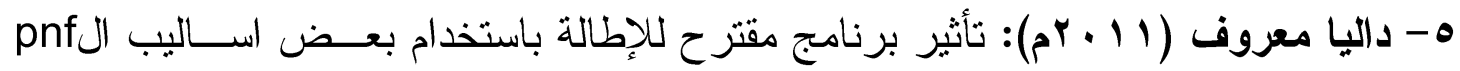
علي المدي الحركي للمفاصل العاملة ومستوي اداء الثقلبة الخلفية البطيئة علي جهاز الحركات الارضية"، رسالة ماجستير غير منشورة، كلية التزبية الرياضية للبنات بالقاهرة، جامعة حلوان.

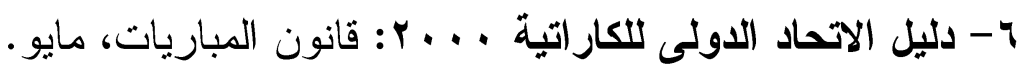

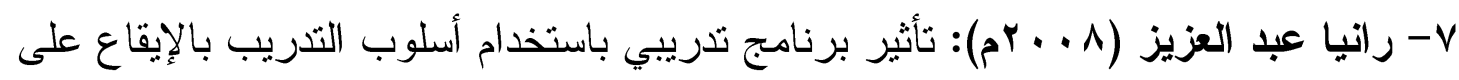

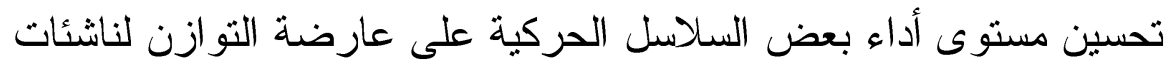

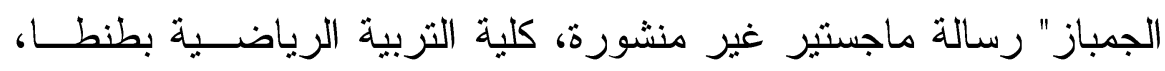
جامعة طنطا، الغربية. 
^- سعيد حسين (• • • بم): برنامج تدريبي في ضوء بعض محددات الاداء المهاري وتأثثر

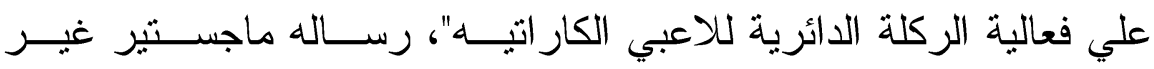
منشوره، كلية التربية الرياضية، جامعة طنطا.

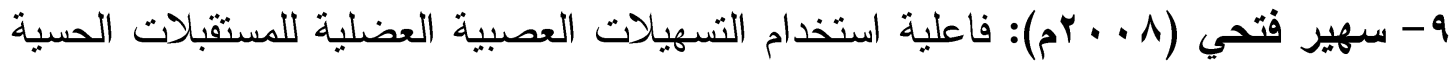

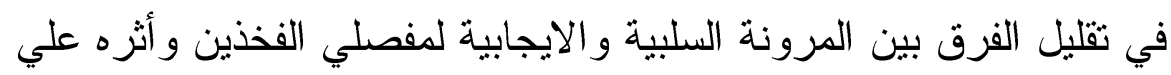
إتقان وتبة الفجوة على عارضة التوازن لدى ناشئات الجمباز الفني"، بحث

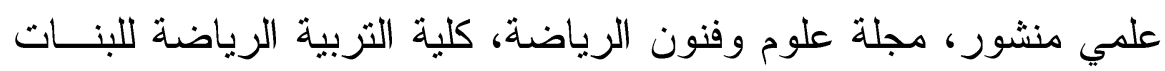

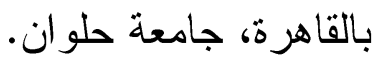

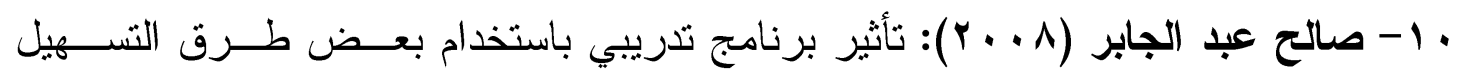

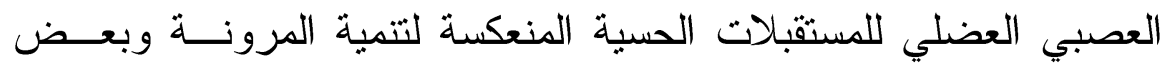

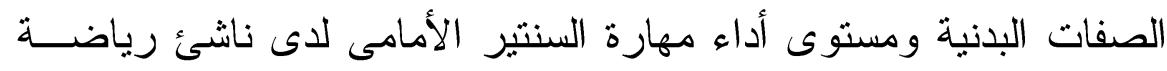

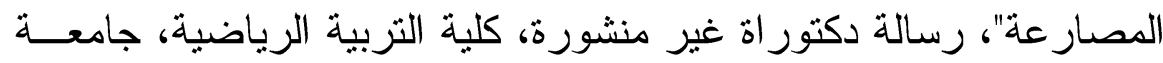
أسيوط

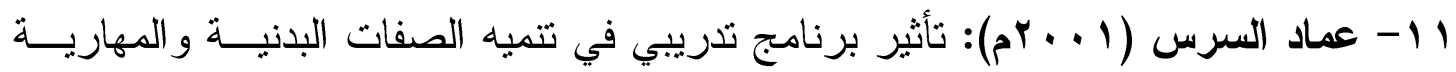

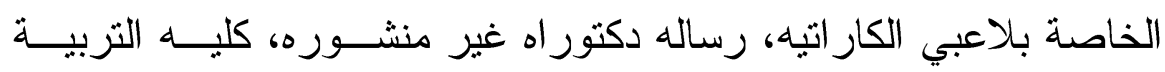

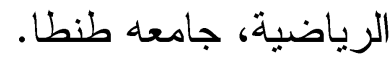

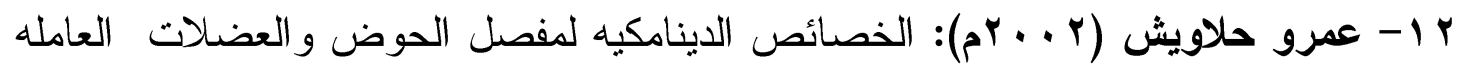

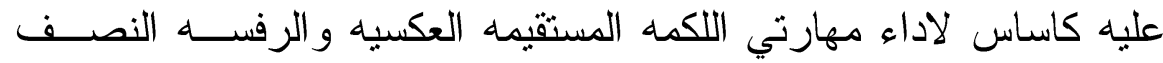

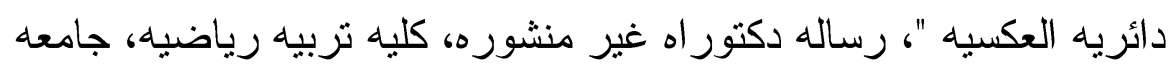
طن

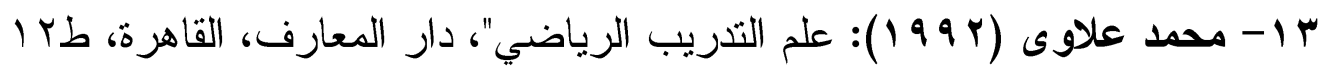

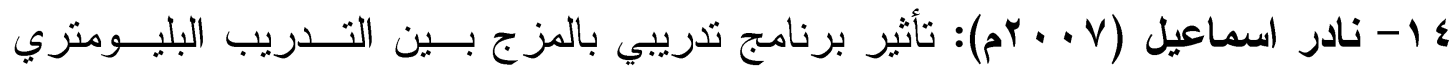

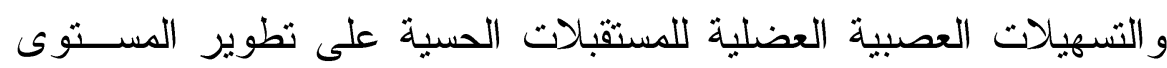

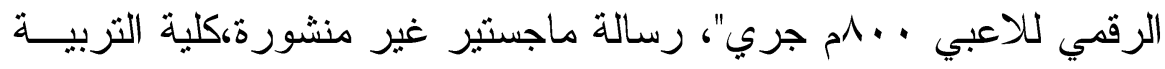

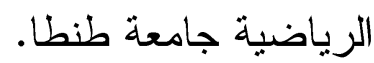
ه 1 - وجيه شمندى (ب9 9 (1م): الكار اتبه الحديث بين النظريه و التطبيق"، مطبعــه خطــاب،

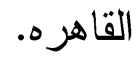




\section{$r \varepsilon r$}

1 ا - وجيه شمندى (؟ 9 (9)): در اسة بعض الخصائص النفسية لدي لاعبي المستوي العالي

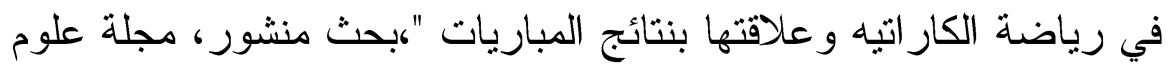
وفنون الرياضة للبنات، القاهرة، العدد الثالث.

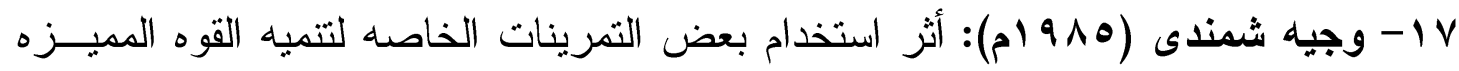

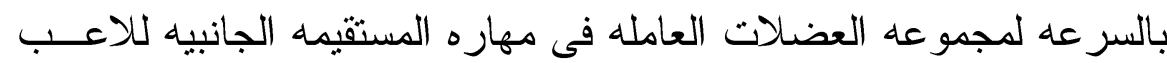

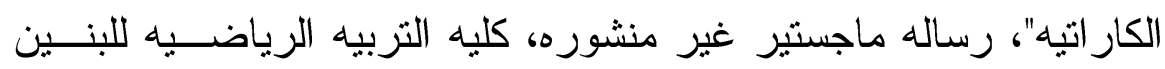
بالاسكندريه، جامعه الاسكندريه.

\section{ثانياً: المراجم الانبليززية}

18- Michael J. \& Alter M.1992: Science of stretching. Champaign, L., L. Human kinetics' USA

19- Michael J. \& Alter M.1995: Science of Flexibility", $2^{\text {nd }}$, Edition human Kinetrce

20- Ward, A. B., \& Kadies, M.2002: The management of pain in spasticity", Disability and Rehabilitation, 20: 443-453

21- Warren young \& Simon Elliott.2001: Acute Effects of static stretching. PNF stretching. And maximum voluntary contraction on Explosive for ce production and jumping performance. Research Quarterly for Exercise and sport, vol 72, No 3. Pp( 273 - 279) September 